\title{
STRATEGIC MANAGEMENT AND ORGANIZATION PERFORMANCE IN THE CONTEXT OF QUALITY MANAGEMENT SYSTEMS
}

\begin{abstract}
The study deals with strategic management of organisations in conformity with quality management system requirements. The aim of the paper is to point out factors with impact on strategic performance of organisations, taking into account strategic concepts of its management. The implementation of a quality management system is a strategic decision that can improve the organization's overall performance. Results of the questionnaire survey focused on identification of industrial enterprises readiness to implement the ISO 9001:2015 are presented in the paper. Survey was also focused on strategic management of the organisations. The survey results recovered implemented strategic tools for performance management in industrial enterprises in the Slovak Republic. There is also described further continued research focussed on correlation between the factors impacting performance of organizations and strategic management tool s in conformity with quality management system.
\end{abstract}

Key words: Improvement, performance, quality, strategic management.

\section{Introduction}

According to Veber and Pernic we can see the meaning of management in a number of tasks. It can be day-to-day issues solution, managing staff to perform planned tasks, creating arrangements to prevent the occurrence of any undesired situations (frauds, damages, penalties), seeking reserves and improving current practices, etc. All these activities should be focused on fulfilling the basic aim that the management of each organization precedes - ensuring its long-term prosperity [1].

Quality management system highlights are based on policies that have been outlined on the basis of experience and good practices and approaches of key players in quality management. Applying quality management policies is important for an organization to improve its performance. It should be seen as an effort to improve

${ }^{1}$ Ing. PhD., Institute of Industrial Engineering and Management, Faculty of Materials Science and Technology in Trnava, Slovak University of Technology in Bratislava, Slovakia, zdenka.babelova@stuba.sk

2 Assoc. Prof. PhD., Institute of Industrial Engineering and Management, Faculty of Materials Science and Technology in Trnava, Slovak University of Technology in Bratislava, Slovakia, jaromira.vanova@stuba.sk

3 Ing. PhD. Institute of Industrial Engineering and Management, Faculty of Materials Science and Technology in Trnava, Slovak University of Technology in Bratislava, Slovakia, vanessa.prajova@stuba.sk 
process performance within an organization to meet customer needs, motivate and engage people in tasks leading to strategic goals.

The principles and tools of quality can improve both the manufacturing process and the overall business process. The goal is to exceed customer expectations to reach the business strategy. Whole quality management is a structured system to satisfy domestic and foreign customers and suppliers by integrating the business environment, continuous improvement and advances with development, improvement and maintenance cycles by changing organizational culture. One of the keys to implementing Total Quality Management (TQM) can be found in this definition. It is the idea that TQM is a structured system. In describing TQM as a structured system, it means that it is a strategy that derives from the internal and external needs of consumers and suppliers, which are defined through day-to-day management and inter- functional management [2].

The adoption of quality management system is a strategic decision for an organization that can help to improve its overall performance and provide a sound basis for sustainable development initiatives [3].

The quality management system is a tool for achieving defined quality goals and for increasing customer confidence. Achieving required quality creates a confidence, which in turn leads to motivation and quality of relationships. The introduction and maintenance of a management system that is designed to continually improve the organization's performance by addressing the needs of stakeholders can also lead to success.

To achieve sustained success, the organization needs strong leadership and clear strategic direction.

\section{Strategic management principles}

Strategic management is the name given to the most important, difficult, and encompassing challenge that confronts any private or public organization. The conflict between the demands of the present and the requirements of the future lies at the heart of strategic management. Change is the central concern and focus of strategic management: change in the environment, change inside the enterprise, and change in how the enterprise links strategy and structure. Strategic management is the process of identifying opportunities to achieve tangible and sustainable success in the marketplace and understanding the risks that threaten achievement of that success [4].

In order for the business strategy to succeed, it must meet the needs of employees, shareholders and customers. The strategy should also take into account current reality and future trends, while increasing the profitability and value of the business at the same time, as well as achieving all other objectives that they set. The business strategy must be flexible enough to cope with volatile and unpredictable 
circumstances, but also specific, sufficiently stable and coherent to manage people's decision-making [5].

Balancing customer and shareholder satisfaction should be the ultimate goal of any business strategy.

Strategic management consist of the analyses, decisions, and actions an organization undertakes in order to create and sustain competitive advantages. This definition captures two main elements that go to the heart of the field of strategic management [6].

First, the strategic management of an organization entails three ongoing processes: analyses, decisions, and actions. Strategic management is concerned with the analysis of strategic goals (vision, mission, and strategic objectives) along with the analysis of the internal and external environment of the organization.

Second, the essence of strategic management is the study of why some firms outperform others. Thus, managers need to determine how a firm is to compete so that it can obtain advantages that are sustainable over a lengthy period of time [6].

Strategic management has four key attributes:

- Directs the organization toward overall goals and objectives.

- Includes multiple stakeholders in decision making.

- Needs to incorporate short-term and long-term perspectives.

- Recognizes trade-offs between efficiency and effectiveness [6].

The strategy theory uses several concepts to express the ideas of the future, such as the vision, mission, and strategic goal, that have to be distinguished. All of them have in common that they indicate the direction and indicatively define the frame in which the strategy will range.

The vision is a draft of the future, created on the basis of ideas anticipating the time, which draws forward with its magical power. The vision shows us how we can be.

If a vision is to play an effective role in strategic management, it should have a strong motivational charge. However, it does not have a target function, i.e., commitment to be fulfilled [7].

The mission, deferently to the vision, is not uniquely focused only on the future. It is based on the ideas of the future included in the vision, but the main meaning is located today. The mission answers the questions: "Who are we and what are we?" And "What is the meaning of our existence?"

The vision outlines, in the most general and conceptual terms, the idea of the future direction and the position of the enterprise [8].

The mission of the enterprise is to express the reason for its foundation and existence. The mission has a general nature and should have a longer term validity. Its simplicity, accuratness and clarity are important. Employee and business partners 
should be familiar with the mission of the company. The mission of the company, as well as the formulation of objectives shared by all employees, should be based on the company's vision.

The mission is focused on the present while the vision is reflected in the future $[8]$.

The mission defines the space in which we will range whem fulfilling the vision. The mission can also remain at the philosophical level and emphasize the values or moral and ethical principles and rules. Organizations that have their missions defined by the philosophical, value orientation, they have a relatively greater scope in the formulation of the strategy to find appropriate pathways, respectively even when searching for ways to respond to emerging environmental changes.

In fact, the mission should include both rational and emotional features.

Vision is clearly heading for the future, the mission keeps us in the reality of the present [7].

A company's mission statement differs from its vision in that it encompasses both the purpose of the company as well as the basis of competition and competitive advantage. Misison statement - a set of organizational goals that include both the purpose of the organization, its scope of operations, and the basis of its competitive advantage. A good mission statement, by addressing each principal theme, must communicate why an organization is special and different [6].

Strategic goals further concretize and put the finishing touches to the future direction of the organization.

They represent certain positions in the environment. They do not mean final positions, but they are perceived as important interdependencies, which always form the basis for further progress toward ultimate success - to fulfill the vision. Strategic goals are already set in a relatively better-knowledgeable environment that allows to complete analyzes and generate realistic ideas about the organization's progress towards the vision.

The strategic goal is the target point of the strategy and formated strategy should bring us to this point, respectively strategic position.

Strategic goals, diferently to the vision, have not only a motivational function. Goals are generally considered as a commitment, and the acceptance of the goal means that we commit to fulfilling it in qualitative, quantitative and temporal terms.

The strategy is generally defined as the conscious determination of basic longterm goals, the establishment of procedures, activities (or parts of the strategy) and the allocation of resources (organization capacities) needed to implement the strategy to enable the objectives to be achieved as quickly as possible.

In conjunction with organizational management, strategy means the intended future of the organization. It is the framework in which is decided, which of the opportunities to be chosen, to determine the nature and direction of the organization. 
The strategy, as part of strategic management, defines what the organization wants to be and common or operational management will ensure how the organization achieves it.

The strategy should precede the long-term (strategic) and operational planning. Strategy means „what" and operative (operation) means „how“.

Quality policy should be consistent with the context and strategic focus of the organization. Top management should perceive and promptly respond to changes in the business environment.

Top management shall establish, implement and maintain a quality policy that is appropriate to the purpose and context of the organization and supports its strategic direction [3].

Strategic management of the organization is a continuous process that requires both - feedback from the organization's internal conditions development and an analysis of the organization's external environment in order to understand how the organization's strategic goals are actually being met. Feedback on actual developments either confirms the validity of existing goals, or may recommend to change them.

The organization shall determine external and internal issues that are relevant to its purpose and its strategic direction and that affect its ability to achieve the intended result(s) of its quality management system [3].

It is necessary for the management of the organization to pay attention to the external business environment that surrounds it. At the same time, it should be based on the knowledge of the internal environment. The goal is to create a comprehensive view of the conditions in which the organization performs and to create the prerequisites for the right strategic direction.

Strategy analysis may be looked upon as the starting point of the strategic management process. Managers must monitor and scan the environment as well as analyze competitors

Analyzing the external and internal environment is a critical step in recognizing and understanding the opportunities and threats that organizations face. A firm`s analysis of the external environment tracks the evolution of environmental trends, sequences of events, or streams of activities [6].

Awareness of external aspects makes it easier to understand the expectations and demands of stakeholders. By accepting their views, organizations can better set up their processes or plan their activities, search for solutions that meet their requirements, assess the risks. Meeting current requirements and addressing the future needs of stakeholders, re-evaluating their expectations poses challenges for the organization.

Internal aspects of the organization and knowledge about these aspects are intended to direct the organization to achieve the ability to provide products and 
services that meet customer requirements and comply with the relevant requirements of the legislation.

Updating the quality policy must be based on an understanding of the internal and external aspects of the organization and related to the strategy of the organization. Changes in strategic direction should also be reflected in quality policy.

Top management shall establish, implement and maintain a quality policy, that is appropriate to the purpose and context of the organization and support its strategic direction [3].

Managers have to determine the strategic direction of the organization, identify relevant and measurable goals, and evaluate their achievement.

It is important to understand the strengths and weaknesses of the organization as well as its environment and current position. It is necessary to determine and acquire the required skills, to adopt the most appropriate style of leadership with which the organization (and its management) can implement the overall strategy.

The goal of the strategic analysis is to identify, analyze and evaluate all relevant factors that can be assumed to affect the final form of enterprise goals and strategies.

\subsection{PIMS (Business Impact of Market Strategy) Model}

Due to growing complexity and increasing business environment dynamics, there is now a need for new quantitative benchmarks for strategic decision making.

The role of strategic management is to ensure long-term survival of the company in the context of market conditions, its opportunities but also constraints. This means that the responsible manager needs to create as much coherence as possible between the organization, the corporate culture and the strategic goals.

PIMS (PIMS = Business Impact of Market Strategy, illustrates particularly the link between the success of the company and the market, the competitive environment as well as other influencing factors.

PIMS is a research program that began in the late 1960s in General Electric, and it was adopted by the Harward Business School in the mid-1970s. PIMS aims to answer the following questions:

- What strategic factors, in terms of sustained return, are crucial to the strategic potential of business success - measured by return on investment (ROI)?

- How are these factors related and how far do they contribute to the potential for success?

- What strategically significant factors and to what extent do they clarify the differences in profitability between enterprises (or strategic business units)?

- How does profitability react to changes in strategies and changes in market conditions? 
Relevant responses can be obtained from an extensive data bank, the most important part of the PIMS research program. The data provides insight into the market experience of various companies that have been explored on the basis of crosssectional analysis of success determinants [9].

Based on the above mentioned empirical survey, relationships between strategic business variables and strategic goals have been demonstrated through statistical testing of patterns (Input/Output relationships) between these factors.

\section{Competitive position}

- Market share

- Relative market share

- Relative customer needs

- Innovation rate

- Relative cost position

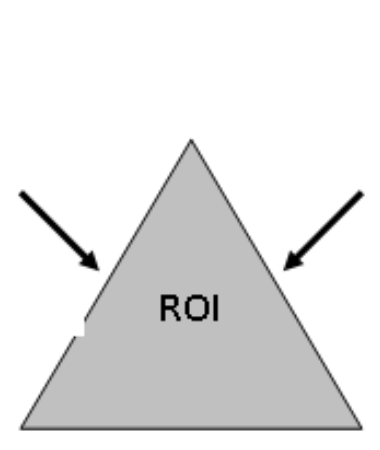

Market attractiveness

- Market growth

- Market concentration

- Marketing intensity

- Negotiating power of customers

\section{Capital and cost structure \\ - Investment intensity \\ - Long-term asset \\ - Illiquid capital \\ - Productivity \\ - Capacity utilization \\ - Vertical integration}

Fig. 1. PIMS - Research model explaining rentability factors (ROI)

Source: [9]

The most important knowledge of the PIMS research program is that 60 to $70 \%$ of the success of the business (or business unit) measured by the ROI (Return on investment) can be derived from impact factors that can be summarized into three categories, as can be seen in figure 1:

- Competitive position (market share, relative market share, relative customer needs, innovation rate, relative cost position).

- Market attractiveness (market growth, market concentration, customer negotiating power, customer concentration, marketing intensity).

- Capital and cost structures (investment intensity, illiquid capital, long-term assets, productivity, capacity utilization, vertical integration) [10]. 
Although the PIMS study has a remarkably high potential for explaining business success in terms of market and strategic data, many results-based studies indicate a link to corporate culture, and integrate organizational variables into an expanded model to provide the best possible explanation for business success. On this basis, besides strategic studies, additional organizational studies focusing on internal organizational factors such as, for example, organizational structures, human resources management, management, and corporate culture.

PIMS according to Eschenbach opens up the possibility to quantify the potential of success and to sustain strategic decisions on the empirical basis. PIMS allows to systematically learn from the experiences of other companies with similar strategic features [9].

\subsection{Techniques for analyzing the external environment of organizations}

The external environment is formed by powers and institutions outside organizations that affect or potentially affect its performance.

We identified two types of environments:

- The general environment (demographic, sociocultural, political, legal, technological, economic, global).

- The competitive environment - consist of industry related factors and has a more direct impact than the general environment.

- Understanding the external context can be facilitated by considering issues arising from legal, technological, competitive, market, cultural, social and economic environments, whether international, national, regional or local [3].

The aim of analyzing the external environment of an organization is not only to examine and assess its current state, but also to anticipate its future development.

Environmental scanning, monitoring, and competitive intelligence are important inputs for analyzing the external environment. Environmental forecasting involves the development of plausible projections about the direction, scope, speed, and intensity of environmental change. Its purpose is to predict change [6].

SWOT analysis is frequently used method for organization evaluation, which includes both, internal and external analysis. It is one of the methods for determining and evaluating the strategic position of the organization.

SWOT analysis consists from strengths, weaknesses, opportunities, and threats analysis. It provides a basic listing of conditions both inside and surrounding the company.

The Strengths and Weaknesses refer to the internal conditions of the firm where the firm excels (strengths) and where it may be lacking relative to competitors (weaknesses). Opportunities and Threats are environmental conditions external to the firm. These could be factors either in the general or competitive environment. In the 
general environment, one might experience developments that are beneficial for most companies such as improving economic conditions, that lower borrowing costs or trends that benefit some companies and harm others. Opportunities and threats are also present in the competitive environment among firms competing for the same customers.

The general idea of SWOT analysis is that a firm`s strategy must:

- build on its strengths,

- remedy the weaknesses or work around them,

- take advantage of the opportunities presented by the environment, and,

- protect the firm from the threats [6].

The SPACE (Strategic Position and Action Evaluation) method is a method that attempts to combine the results of the analysis of the external and internal environments into one set and to create a primal idea of the strategy. Differently to the the SWOT analysis, it uses specific defined parameters to describe charcteristics of environment. The external environment is expressed through two aggregated criteria environment stability and industry attractiveness. The internal environment is expressed by two criteria - the competitive advantage of the organization and the financial strength of the organization.

PEST analysis or STEP analysis examines factors that affect the organization directly from its surroundings. It's an abbreviation for Political, Economic, Social and Technological analysis. This model is widespread in the area of legislation and then referred as SLEPT analysis. The STEP/PEST analysis is based on past development that try to predict future development and to analyze future environmental impacts in the mentioned four areas. The intent of the analysis is to alert the company to possible threats and opportunities. The analysis of the external environment should focus primarily on revealing the development trends that can significantly affect the company in the future [11].

The implementation of evaluation and analysis of individual factors of PEST analysis includes:

Political - factors related to the execution of political power, political stability, legislation regulating entrepreneurship, consumer protection, tax policy, labor law.

Economic - factors related to the development of economic processes, economic growth, gross domestic product, monetary rates, loan policy, inflation.

Social - (or also socio-cultural) factors, lifestyle factors, consumer habits of customers, demographic factors, educational level, lifestyle changes.

Technological - development of new materials, processes, technologies, state spending on research. 
It is important to distinguish the direct impacts on the organization, that the organization is struggling with and have to respond to, and the influences that indirectly or mediated influence the organization.

Scenario Analysis - is a more in-depth approach to environmental forecasting that involves experts' detailed assessments of societal trends, economics, politics, technology, or other dimensions of the external environment. It usually begins with a discussion of participants thoughts on ways in with societal trends, economics, politics, and technology may affect an issue [6].

Scenarios are an overview of potential events and their consequences, providing contexts for managers to make decisions. With the opportunity to consider a whole range of future events, their decisions are more qualified and a strategy based on this deeper understanding has a greater chance for success. Scenarios do not predict the future but explain the causes of change. And then it helps managers get more control when market conditions change [5].

Porter`s five-forces model of industry competition developed by Michael E. Porter has been the most commonly used analytical tool for examining the competitive environment, especially the ability of firms in that industry to set prices and minimize costs. It describes the competitive environment in terms of five basic competitive forces:

- The threat of new entrants.

- The bargaining power of buyers.

- The bargaining power of suppliers.

- The threat of substitute products and services.

- The intensity of rivalry among competitors in an industry.

The intensity of these factors determines, in large part the average expected level of profitability in an industry [6].

\subsection{Analyzing the Internal Environment of organizations}

Understanding the internal context can be facilited by considering issues related to values, culture, knowledge and performance of the organization [3].

When analyzing the internal environment, organizations typically use financial analysis.

Financial analysis is an integral part of the business analysis. The results of the financial analysis can provide valuable information not only for the organization's own needs but also for interested groups that are not part of the organization but are linked with organization economically, financially, etc. [12].

Financial analysis constitutes valuation of the past, present and anticipated future of the organization's financial management. Its aim is to know the financial 
health of the organization, to identify weaknesses that could lead to problems in the future and determine the strengths on which organization could base upon [13].

The financial statements - balance sheet, profit and loss account and cash flow are the sources of gathering information for the organization's financial analysis.

The organization shall determine and provide the resources needed for the establishment, implementation, maintenance and continual improvement of the quality management system. The organization shall consider:

- the capabilities of, constraints on, existing internal resources;

- needs to be obtained from external providers [3].

Managers look for the most important resources their organization relies on, focusing on strategic resources - these are some of the extraordinary items that can explain why an organization is more successful than its competitors.

Resources can grow and diminish, as well. Since the performance of an organization directly reflects the availability of resources at any moment, it is necessary to understand how these resources develop over time and how to control the process [5].

The organization needs to recognize its resources and one of the options to analyze them is using the VRIO method.

VRIO Analysis (Value, Rarity, Imitability, Organization) is a strategic planning tool used by organizations to implement effective business decisions. It is the method of internal organization analysis. It used to be used to identify and evaluate resources in your organization.

This tool was originally developed by Barney, in his work „Firm Resources and Sustained Competitive Advantage". The author identified four attributes that firm's resources must possess in order to become a source of sustained competitive advantage in this work. According to him, the resources must be valuable, rare, imperfectly imitable and non-substitutable. His original framework was called VRIN. Barney has introduced VRIO framework, which was the improvement of VRIN model in his later work „Looking Inside for Competitive Advantage”, in 1995. VRIO analysis stands for four questions that ask if a resource is: valuable? rare? costly to imitate? And is an organization organized to capture the value of the resources? [14].

A resource or capability that meets all four requirements can bring sustained competitive advantage for the company.

The Value of Resources - does the resource deliver value by enabling a business to use opportunities or to defend itself from threats? Does the resource help raise customers' perceived value? How expensive is the source, how easy is it to get it on the market? 
Rarities - how rare is the resource or limited? Resources that only one or few organizations can get are considered rare. Rare and valuable resources provide a temporary competitive advantage.

Imitability - how difficult (easy) or costly to imitate the source? Maybe buy it, or to replace it at a reasonable price?

Organization - Is the support available for an existing organization, can the organization use it correctly? The sources themselves do not provide any benefits if they are not organized to bring value. The organization must organize its management systems, processes, policies, organizational structure so that it can fully exploit the potential of its valuable, rare and costly imitative resources and its capabilities. Thereafter, the firm can achieve a lasting competitive advantage.

\section{Performance of the organization and its evaluation}

Building a strategy requires understanding all the elements the organization creates, along with information that explains why its performance is like it is.

An internal analysis of the organization would not be complete unless you evaluate its performance and make the appropriate comparisons. Determining a organization`s performance requires an analysis of its financial situation as well as a review of how well it is satisfying a broad range of stakeholders, including customers, employees, and stockholders [6].

In order for the organization to succeed, it must succeed in the market and achieve its goals. Within the internal aspects, management of the organization have to monitor and also evaluate its performance.

According to Nenadál, performance, productivity and quality have many common features, which he describes as follows. Productivity is tied to the need to efficiently use the resources and inputs that are required to perform the processes. The better are utilized material and information inputs, as well as material and human resources, the higher is the productivity. However, the productivity also determines the degree of achievement of the results (especially in view of the objectives set for a particular process or organization). When these results are directed to meeting customer requirements and legislative requirements, it is clear that both quality and productivity are factors that affect directly and significantly performance of organization [15].

The European Foundation for Quality Management (EFQM) defines performance as extend of results achievement by individuals, groups, organizations and processes [16].

In a simplified way, we can say that the company's performance is determined by the performance of people and processes. Process and people's performance are mutually depend on one another. It can be hardly to imagine powerful and 
sophisticated processes to be are processed by inefficient people. The more sophisticated and challenging processes, the more efficient and more effective people are needed, with increasing extend of self-regulation and competencies. (Hroník 2007)

Veber and Pernica define prosperity as a situation in the development of an organization that ensures the successful, complex and long-term fulfilling of its function [1].

According to Veber and Pernica, productivity is a degree of transformation (utilization, capitalizing) of resources in the form of useful outputs fulfilling the function of the organization [1].

Karlöf and Lövingsson point out that the term efficiency is often, but incorrectly, used as a synonym for productivity, that is the ability to create something regardless of its market value. Productivity simply requires that what is produced will also control the value on market [17].

Wagner distinguishes between two performance dimensions, which are in fact answers to the simple question of what can be done to drive a particular goal. The difference between two basic answers explains the translation of two words in one sentence in English. The first of them "do the right things", points to performance in terms of the choice of activity we are doing. This performance dimension is usually referred to as effectiveness. The second of the answers "do the things righ" points to performance in terms of how we perform the chosen activity. This dimension is usually referred to as efficiency [18].

One of the most common conceptual frameworks for value for money (VFM), what means the optimal use of resources to achieve the intended output is an approach that provides a framework for analysis based on economy, efficiency and effectiveness. Three criteria (3E) are use this approach:

- Economy: the effort to minimize the cost of used sources (inputs), lower input consumption (i.e. spending less), it assesses the extent to which inputs are purchased in the right amount and at the right price. This is to minimize resource costs (inputs) with respect to the corresponding quality.

- Efficiency: The relationship between the outputs and the sources from which they are produced (i.e. spending well), it evaluates how efficiently the project delivers its outputs, taking into account the extent to which inputs are converted to outputs and their cost effectiveness.

- Effectiveness: the relationship between planned and actual results - (i.e., spending wisely), assessing the extent of the impact of the output transformation on the results and the usefulness of this conversion.

In addition to these three "E" is somewhere applied fourth E:

- Equity: Equity: the extent to which services are available and available to all people for whom they are intended - (i.e., spending fairly). Some people may 
receive different levels of service for reasons other than differences in their levels of demand.

It means that development is valuable only if it is fair. Approach 4E maps the chain of results describing the relationship between inputs, outputs, results and impacts at the level of the required interventions [19].

In order for the organization to find out its performance and efficiency it is essential to measure outputs of processes that affect the resulting product or service. The performance measurement system requires a systematic approach, i.e. to identify indicators to monitor internal or external data and information. Typically, for each process is identified the key indicator - the Key Performance Indicator (KPI) that represents the target or a predetermined value.

The results need to be analyzed and evaluated to determine the actual situation.

The organization shall determine:

- What needs to be monitored and measured;

- The methods for monitoring, measurement, analysis and evaluation needed to ensure valid results;

- When the monitoring and measuring shall be performend;

- When the results from monitoring and measurement shall be analysed and evaluated [3].

As Tyson and Jackson explained, the performance of any organization consists of a whole range of elements that must be somehow integrated. Performance is determined by achieving or get beyond set business goals and maybe social goals and responsibilities. Performance is always judged from the point of view of a particular evaluating part.

This is not just about the different views of different interest groups, but there are also differences within the organization, as the marketing department's goals may differ overall from those of the production or financial department [20].

According to Tyson and Jackson, the evaluation depends on the value scale of the evaluator. For different levels, these scales will vary, in other words, the bases on which the assessment is based are not unchanged. According to the authors, we have to look at levels of performance and their comparison with system goals and their social reasons [20].

If we want to measure performance, we have to do it in comparison with the defined, the target value of the result [15].

As stated by Šulák and Vacík, there are several approaches to measuring and managing the company's performance:

- Classic approaches - they use a range of financial indicators to measure performance and aim endeavor to achieve maximum profit, e.g., classical financial analysis. 
- Modern approaches - they consider the economic gain, which also takes into account alternative costs (cost of lost opportunities). They try to eliminate the shortcomings of classical approaches, e.g., EVA, discounted cash flow.

- Complex Approaches - in addition to financial indicators, they use non-financial indicators, which focus on customers, employees and business processes, e.g. Balanced Scorecard [21].

\section{Concepts for Measuring and Managing Performance}

Performance is an economic category that is closely related to the system view of its measurement and evaluation. Setting up and implementing systems to ensure good performance towards meeting organizational goals and pre-outs is the most complex area of managerial activity. Available literature describes several performance management systems/concepts that can be used in organizations.

\subsection{Key performance indicators (KPI)}

As Parmenter argues, many companies are working with the wrong measures, many of which are incorrectly termed key performance indicators (KPIs). Very few organizations really monitor their true KPIs. The reason is that very few organizations, business leaders, writers, accountants, and consultants have explored what a KPI actually is. There are four types of performance measures (see Figure 2) [22].

- Key result indicators (KRIs) tell you how you have done in a perspective or critical success factor.

- Result indicators (RIs) tell you what you have done.

- Performance indicators (PIs) tell you what to do.

- KPIs tell you what to do to increase performance dramatically.

Many performance measures used by organizations according to Parmenter argues (Parmenter 2007) are thus an inappropriate mix of these four types.

Parmenter uses an onion analogy can be used to describe the relationship of these four measures. The outside skin describes the overall condition of the onion, the amount of sun, water, and nutrients it has received; and how it has been handled from harvest to the supermarket shelf. The outside skin is a key result indicator. However, as we peel the layers off the onion, we find more information. The layers represent the various performance and result indicators, and the core represents the key performance indicator [22]. 


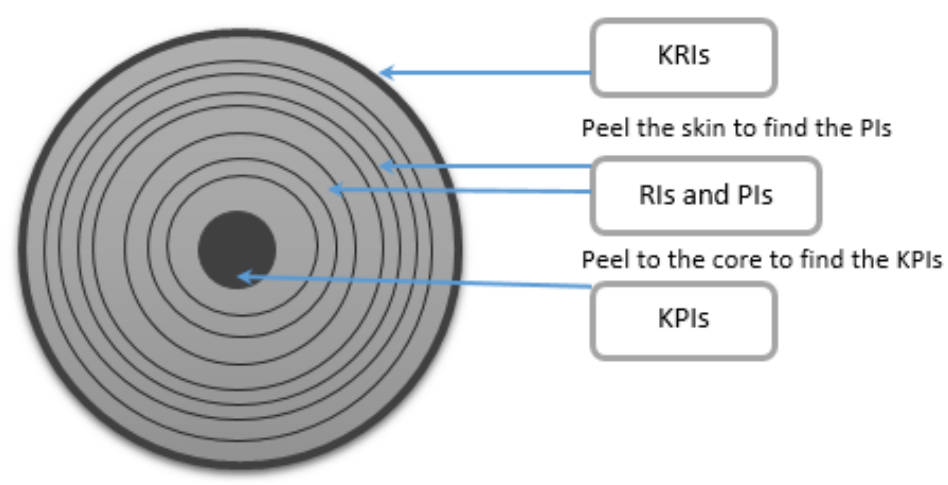

Fig. 2. Four Types of Performance Measures

Source: [22].

As Parmenter defines, the common characteristic of Key result indicators (KRIs) is that they are the result of many actions. They give a clear picture of whether you are traveling in the right direction. They do not, however, tell you what you need to do to improve these results. The performance measures that lie between the KRIs and the KPIs are the performance and result indicators (PIs and RIs). The performance indicators, while important, are not key to the business. The PIs help teams to align themselves with their organization's strategy. PIs are nonfinancial and complement the KPIs; they are shown with KPIs on the scorecard for each organization, division, department, and team. KPIs represent a set of measures focusing on those aspects of organizational performance that are the most critical for the current and future success of the organization [22].

Parmenter defined the seven characteristics of KPIs:

- Are nonfinancial measures (e.g., not expressed in dollars, yen, pounds, euros, etc.);

- Are measured frequently (e.g., 24/7, daily, or weekly);

- Are acted on by the CEO and senior management team (e.g., CEO calls relevant staff to enquire what is going on);

- Clearly indicate what action is required by staff (e.g., staff can understand the measures and know what to fix);

- Are measures that tie responsibility down to a team (e.g., CEO can call a team leader who can take the necessary action);

- Have a significant impact (e.g., affect one or more of the critical success factors (CSFs) and more than one BSC perspective);

- They encourage appropriate action (e.g., have been tested to ensure they have a positive impact on performance, whereas poorly thought-through measures can lead to dysfunctional behavior) [22]. 


\subsection{Competency Based Management (CBM)}

Management by competencies or competency based management is a management concept based on balancing the employees' real competences and on skills requirements that require jobs and job roles. That indicates, that competencies can be considered only in relation to a particular job role, job position or job function.

In an organization, we can distinguish people whose main role is to provide immediate work performance at their job position, as well as people whose task is to set requirements for this performance. In both cases, the competence of these groups of people is important due to their roles and tasks.

The competence of the manager can be defined as his ability to perform the function resulting from his position within the organizational management structure and at competency as the ability at the given functional level, in a given functional position to achieve the required work performance, respectively, the required level of results [23].

In a simplified way, we can say that competencies are generally perceived as a sum of employees' work behavior and performance results achieved through human resources.

Another authors recognize competency based management (CBM) (also cited as Competency-Based/Human Resource/Management) as currently considered to be the most progressive way of staffing in organizations. Various members of the organization (employees and managers, or business executives) are often involved, often with contributions from external consultants from companies specializing in their implementation to companies [24].

\subsection{Management by Objectives (MbO)}

Objective oriented management puts forward the setting and adoption of objectives as a management tool in all areas of corporate responsibility.

Objectives should be set to be clear, measurable and mutually not exclusive. Ideally, they should be able to be quantified. If objectives are quantifiable, it is possible to use computer-processed mathematical, statistical models and other appropriate IT-supported techniques to achieve and control them.

According to Russell-Walling, the concept of Management by Objectives has now been introduced by the until now actual, classical business thinker Peter Drucker in his breakthrough work of 1954 "The Practice of Management". MBO requires focusing on results rather than on activities. This is why it is sometimes called management by results [25]. 
Drucker, as one of the first, emphasized the limitation of a classical microeconomic approach based on financial performance, efficiency and preference of maximum profit, or later economic profit expressed as a standard (EVA) as a basic financial and value evaluation criterion. He point out that it is imperative for businesses first to synchronize managers' interests with corporate objectives, as these are not always consistent, which necessarily leads to inefficient management of whole business.

The goal management process starts optimally at senior management by identifying general business objectives. Preliminary objectives should define what is to be achieved in the given planning period in terms of the purpose and mission of the organization, based on an analysis of internal strengths and weaknesses and external opportunities and threats. These objectives are, however, modifiable, because one of the purposes of this technique is to motivate employees by having the opportunity to participate in the creation of objectives [26].

In this way, the MBO structure should establish a direct link between the management strategy and its application at lower levels of the organization. In order to keep the whole process within the set limits, the progress towards objectives have to be monitored regularly and staff performance have to be assessed. The rating must be accompanied by a feedback. This feedback according to Drucker means that whenever you make a key step or decision, you have to write down what you expect from it. Once you get the results, you regularly check to what extent your expectations match what has actually been done. This feedback can be used to decide where you are good, where you are bad, what you need to change, and where to add. Those who were successful and achieved their goals are then rewarded. In the pure form of MBO those who failed are punished [25].

The objective-based management technique is based on reaching an agreement between managers and their subordinates on objectives and performance standards, on the basis of which they will be further assessed [26].

\subsection{Balanced Scorecard (BSC)}

Kaplan and Norton have created a new and revolutionary approach to measuring business performance. However, the balanced scorecard does not only allow performance measurement based on four perspectives but also helps to communicate, coordinate, manage and change business strategy. It is not a tool for formulating a strategy, but a tool for changing an existing strategy and eliminating contradictions between strategic and operational planning.

The balanced scorecard is a tool for creating and implementing a futureoriented strategy towards a learning organization and highlighting the human resources position in the organization's management system. It provides a "useful 
language" for communicating visions and strategies across the organization and at all levels. It helps to align the process of implementing the strategy with the organizational culture, enables employees to understand the organization's strategy and increases their motivation. The balanced scorecard helps transform the organization's strategy into operational goals.

Kaplan and Norton formulated what makes a balanced scorecard special. Four characteristics stand out:

- It is a top-down reflection of the company's mission and strategy. By contrast, the measures most companies track are bottom-up: deriving from local activities or ad hoc processes, they are often irrelevant to the overall strategy.

- It is forward-looking. It addresses current and future success. Traditional financial measures describe how the company performed during the last reporting period without indicating how managers can improve performance during the next.

- It integrates external and internal measures. This helps managers see where they have made trade-offs between performance measures in the past, and helps ensure that future success on one measure does not come at the expense of another.

- It helps you focus. Many companies track more measures than they can possibly use. But a balanced scorecard requires managers to reach agreement on only those measures that are most critical to the success of the company's strategy. Fifteen to twenty distinct measures are usually enough, each measure customdesigned for the unit to which it applies [27].

The concept of balanced scorecard came out of the realization that no single performance indicator can capture the full complexity of an organization's performance. In particular, financial indicators have well-known weaknesses, such as capturing the impact of decisions with a significant time lag. As a result they tend to be less proactive indicators of potential problems than operational (non-financial) indicators [28].

According to Kaplan and Norton, the balanced scorecard represents a management and measurement system. What you measure is what you get. The balanced scorecard focuses on four performance perspectives:

- Financial Perspective

Financial performance is key to business survival. It is also important to satisfy the shareholders. The financial perspective and its objectives are the focal point of the objectives and indicators of other perspectives. Each indicator should be linked to a causal link that will lead to an increase in the company's financial performance.

- Customer Perspective

Kaplan and Norton wrote the balanced scorecard concept at a time when companies began to become more aware of the customer's view and admitting the fact 
that finding a new customer is much more costly than keeping an existing one. In order for the company to see its business from this perspective, it has to measure to what extent customers are satisfied with the products and services provided [25].

- Internal Business Perspective

This is an internal perspective, self-oriented (introspective), measuring the performance of all the key business processes that make up business. Measurements themselves depend on the nature of business [25].

- Innovation and Learning Perspective

To measure potential future performance with an emphasis on the need to invest in the development of people in the organization.

Applying to these four perspectives through the balanced scorecard concept allows to combine short-term, operational management with long-term business strategies.

The Balanced Scorecard integration and coordination features have been used by the research teams of the University of Lueneburg and the University of St. Gallen as an incentive to use the balanced scorecard methodically to create so called Sustainability Balanced Scorecard (SBSC). The social and environmental aspects and indicators of the extended management tool, is a good starting point for sustainable corporate management. The SBSC is designed to improve the performance of the business in all three dimensions of sustainability, and these dimensions are integrated into the enterprise because of their strategic importance. Focusing the corporate strategy on all three of these dimensions can be described as sustainable value and efficiency oriented management.

\section{Research}

The implementation of a quality management system is a strategic decision that can improve the organization's overall performance. In the framework of this paper, our goal was to identify strategic management issues in the context of fulfilling the requirements of ISO 9001:2015 on the basis of questionnaire survey and the secondary research. Questionnaire survey was focused on identification of industrial enterprises readiness to implement the ISO 9001:2015. The data were then processed and evaluated by mathematical, statistical and graphical methods. Survey was also focused on strategic management of the organisations. The survey results recovered implemented strategic tools for performance management in industrial enterprises in the Slovak Republic. The questionnaire survey was implemented at the end of 2016 and at the beginning of 2017.

Survey was focused on large and medium-sized enterprises in Slovakia. When classifying large, medium and small organizations, we only followed the criterion of staffing for the simplification. For medium-sized businesses we considered enterprises 
with a staff between 51 and 250 , over 250 employees we considered enterprises as large.

In order to complete the questionnaire, 500 large and medium-sized organizations were addressed. There were 128 questionnaires filled in, out of which 125 were correctly filled, representing $25 \%$ of the number of addressed organizations. The structure of respondents, by size, was $38 \%$ of large organizations and $62 \%$ of medium-sized organizations (see figure 3 ).

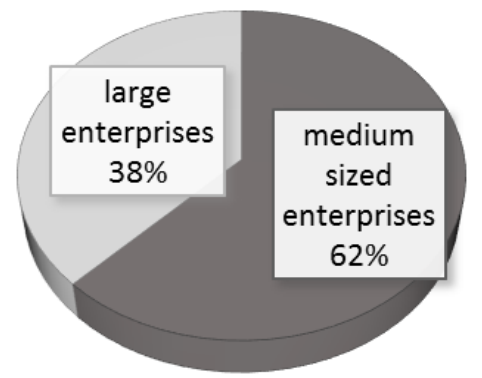

Source: own

Fig. 3. Structure of respondents by size

The organizations, involved in the survey, were from different industries. The largest part represented automotive industry (38\%). "Other industries" represented wood industry, metallurgy, mining, rubber industry and textile industry (see figure 4).

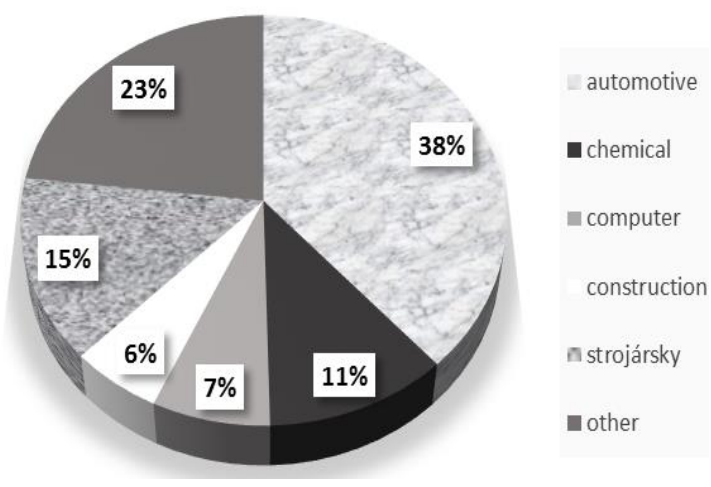

Source: own

Fig. 4. Structure of respondents by industry 
Individual responses to questions aimed on strategic management were analysed from a variety of perspectives, some findings were irrelevant to the survey focus, and others could be interpreted as important and confirming assumptions.

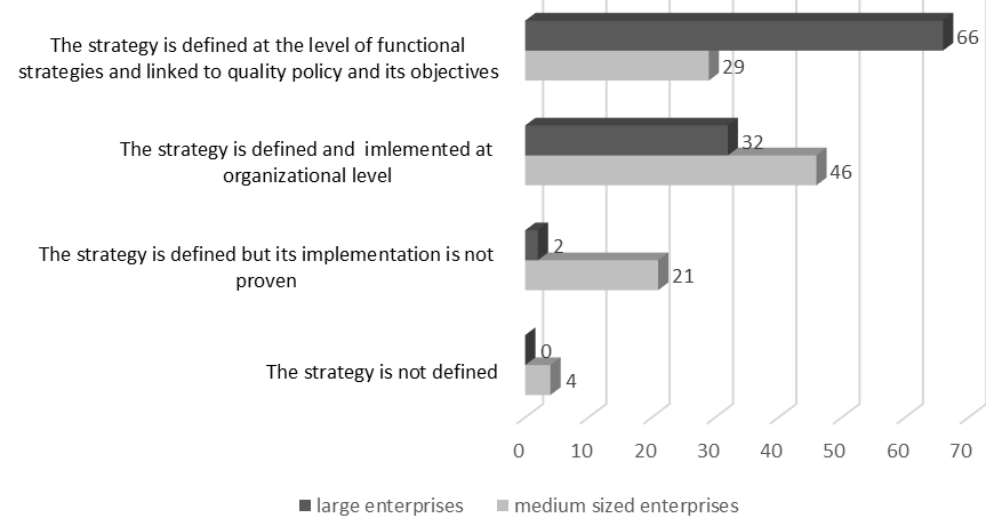

Fig. 5. Levels of strategy implementation in organizations [in \%] Source: own

There were stated two main research issues in the area of strategic management:

- Do more than $50 \%$ of respondents have a strategy that is linked to quality policy?

- Do more than $50 \%$ of organizations consider both internal and external aspects and identifies the risks and opportunities for achieving the goals?

As survey showed, $66 \%$ of large organizations have developed a strategy at the level of functional strategies and linked to quality policy and its objectives, but only $29 \%$ of medium-sized organizations do so. The $46 \%$ of medium-sized organizations have an organization-wide strategy. We did not find any significant differences in responses in comparison by sector. As shown in Fig. 5, first research question was confirmed only in large organizations. 


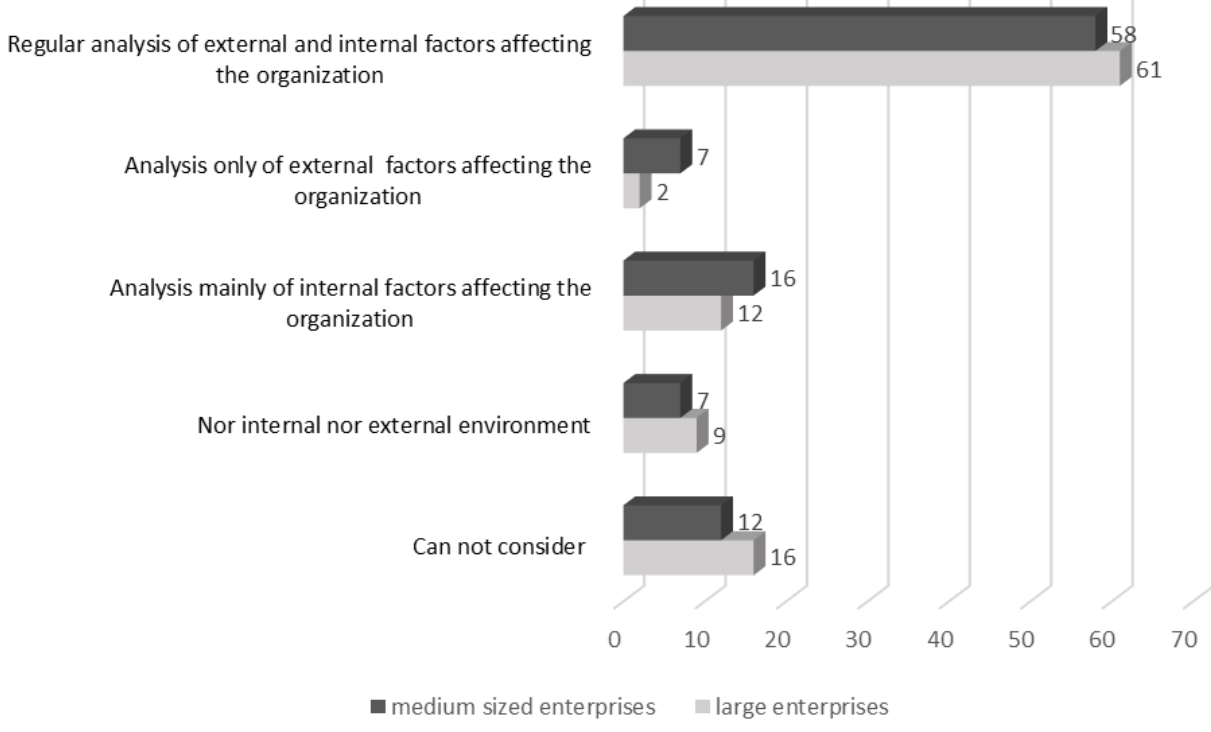

Source: own

Fig. 6. Levels of strategy implementation in organizations [in \%]

When monitoring information on the internal and external influencing the organization performance, major of organizations analysis both, external and internal factors on regular basis.

We also focused on the identification and assessment of the internal aspects of the organization. We asked if the organization identifies its strengths and weaknesses. Survey showed, that $56 \%$ of medium and up to $64 \%$ of large businesses tries to identify their strengths and weaknesses and use them to achieve results, improve their business, to eliminate their weaknesses. As further survey indicated, organizations are less committed to identify external aspects than to identify internal aspects. Only $48 \%$ of medium and $54 \%$ of large organizations identify opportunities and threats to the external environment to achieve the results and improve.

Based on the survey, we found out that second research question has been confirmed in its first part and more than $50 \%$ of organizations are considering internal aspects of the second part, considering external aspects and identify risks and opportunities, only to large organizations have confirmed the achievement of the stated goals.

Based on the facts mentioned above, we would like to conclude that organizations, especially large ones, use strategic management, which is also linked to 
quality objectives, and use management approaches from a long-term perspective. Medium-sized organizations need to develop strategic management areas and develop their strategy statements, also with regard to the lower management levels, respectively functional areas and quality policy.

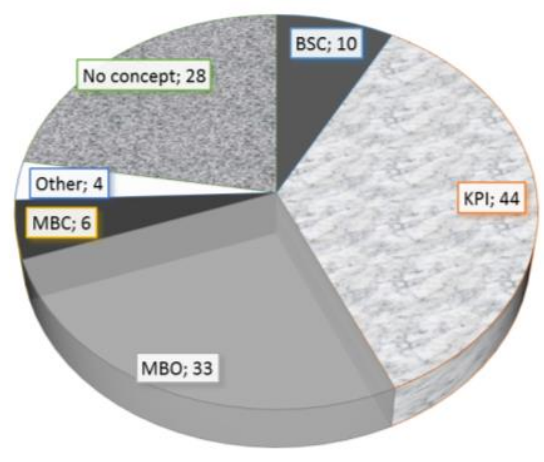

Fig. 7. Used concepts of performance management and improvement [in \%] Source: own

We also investigated what organizational performance management concepts are used to implement their strategies and strategic objectives. When dividing the file into large and medium-sized organizations, we did not notice significant differences in the use of performance management concepts, so there were examined resumed results for the entire file. As shown in Fig. 7, the $44 \%$ of organizations use KPI performance management and $33 \%$ management by objectives. The $28 \%$ of organizations said they did not use any concept of performance management.

The results point on the fact that organizations have involved performance management concepts to a greater extent than the strategic management tools themselves. In the future, we would like to focus on analysis of this discrepancy that revealed presented finding. The focus of research should be focused on investigation of the correlation between used management concepts, the organizational performance of organizations and strategic management tools in compliance with quality management systems.

\section{Conclusion}

The current period of time can be describet as the beginning of the 4th Industrial Revolution, whose characteritic feature is the digitalization of production processes. Obviously, the digitization issue will significantly affect also the aim of quality management. In particular, the whole area of manufacturing and inter- 
operational control and partially the exit control will becom the domain of computing. At the same time, quality management will need to focus on processes that current ISO standards do not address at all. These are primarily external processes or processes that have the pre-production character, resp. post-production and bud are currently neglected [29].

For performance and efficiency to be known, it is essential to analyze and evaluate the results. The organization should adpopt appropriate indicators for output measurement. It is important for the data to reflect the actual state of the management system and, after analysis, to be a good basis for a possible improvement of the organization's management system. It is important that the organization hvae to evaluate the performance and efficiency of the quality management system.

\section{Acknowledgment}

The paper is a part of VEGA project No. 1/0348/17 „The impact of the coexistence of different generations of employees on the sustainable performance of organisations“.

\section{Bibliography}

[1] Veber, J. at al. Management. Základy, prosperita, globalizace. Praha: Management Press. 2001. pp. 700 ISBN 80-7261-029-5.

[2] Ramaj, V., Hajdari, B. Havolli R. „Total Quality Management in the Companies of the Republic of Kosovo.” In Kvaliteta kao razvojni koncept. 2018. pp. 93-102. ISBN 978-953-8067-11-2.

[3] ISO 9001:2015. Quality management system Requirements. 2016. pp 60.

[4] Salvendy, G. Handbook of Industrial Engineering. Third Edition. New York: John Wiley \& Sons.2001. pp. 2798. ISBN 0471-33057-4.

[5] Kourdi, J. Podniková strategie. Pruvodce rozvojem vašeho byznysu. Brno: Computer Press. 2011. ISBN 978-80-251-2725-4.

[6] Dess, G.G., Lumpkin, G.T., Eisner, A.B., McNamara, G.: Strategic Management. Creating Competitive Advantages. Irwin:McGraw-Hill. 2013. pp. 452. ISBN -13: 9780077161095.

[7] Papula, J. "Vývoj teórie strategického manažmentu pod vplyvom meniaceho sa prostredia." In KARTPRINT, Bratislava 2004. pp.272 s. ISBN 8-88870-40-2.

[8] Slávik, Š.: "Strategické riadenie podniku” In Sprint vfra, Bratislava 1999. pp. 284, ISBN 80-88848-41-5.

[9] Eschenbach at al. Controlling. Praha: ASPI publishing, 2000. pp. 816, ISBN 8085963-86-8. 
[10]Sackmann, S. A. Assessment, Evaluation, Improvement: Success through Corporate Culture. Gütersloh: Verlag Bertelsmann Stiftung, 2006, [cit: 23.1.2012] www.bertelsmann-stiftung.de/cps/rde/xchg/SID-0A000F0A

5C4DBD1D/bst/hs.xsl/prj_7521.htm .

[11]Keřkovský, M. and Vykypěl O. Strategické ř́zeni: teorie pro praxi. Bratislava: C. H. Beck, 2006. ISBN 80-7179-578-X.

[12]Pavelková, D.and Knápková, A . "Podnikové finance: studijní pomůcka pro distanční studium.” 4. ed.,. Zlín: Univerzita Tomáše Bati ve Zlíně, 2008. 293 pp. ISBN 978 $80-7318-732-3$.

[13]Blaha, Z. S., Jindřichovská, I. Jak posoudit finanční zdraví firmy: finanční analýza pro investory, bankére, manažery, podnikatele a drobné akcionáře . 2. vyd. Praha: Management Press, 1995. pp. 159. ISBN 80 - 85603 - 80 - 2.

[14]14.Barrney J. B. „Firm Resources and Sustained Competitive Advantage” Jpurnal of Management . vol 17. pp 99-120, No 11.

[15]Nenadál, J. 2004. "Měření v systémech managementu jakosti." Praha: Management Press. pp. 335. ISBN 80-7261-110-0.

[16]EFQM. Excellence Model. 2003. Brussels: EFQM, pp. 35.

[17]Karlöf, B.and Lövingsson F. H. "Management od A do Z. Klíčové pojmy a termíny." Brno: Computer Press. 2006. pp.309. ISBN 80-251-1001-X.

[18]Wagner, J.. "Měření výkonnosti. Jak měřit, vyhodnocovat a využívat informace o podnikové výkonnosti." 2009. Praha: Grada Publishing. pp. 248. ISBN 978-80-2472924-4.

[19]National Audit Office. Assessing value for money. [cit: 19.9.2017] https://www.nao.org.uk/successful-commissioning/general-principles/value-formoney/assessing-value-for-money/

[20]Tyson, S. and Jackson, T. 1997. “Organizační chování.” Praha: Grada. pp. 232. ISBN 80-7169-296-4.

[21]Šulák, M. and Vacík, E. Měření výkonnosti podniku. Praha: Vysoká škola finanční a správní, 2005. pp.89. ISBN 80-86754-33-2.

[22]Parmenter, D. "Key Performance Indicators. Developing, Implementing, and Using Winning KPIs.” Second Edition. New Jersey: John Wiley \& Sons.2010. pp. 299. ISBN 978- 0-470-54535-7.

[23]Čambál, M. - Chlpeková, A. - Gyurák Babel’ová, Z. - Lenhardtová, Z. “Manažment podniku: klúčové manažérske kompetencie." 1. vyd. Bratislava : Nakladatel'stvo STU, 2013. Pp. 354 s. ISBN 978-80-227-3926-9.

[24]Veteška, J. and Tureckiová, M. Kompetence ve vzdělávání. Praha: Grada Publishing. 2008. pp 160. ISBN 978-80-247-1770-8.

[25]Russell-Walling, E. Manažment. 50 myšlienok, ktoré by ste mali poznat'. Bratislava: SLOVART. 2012. pp. 208 .ISBN 978-80-556-0419-0. 
[26]Bělohlávek, František at al "Management. "Olomouc: Rubico. pp. 642. ISBN 8085839-45-8.

[27]Kaplan R. S. and Norton D. P. "Putting the Balanced Scorecard to Work." Harvard Business Review, pp 134 - 147. Sept.-Oct. 1993.

[28]Epstein, M. J.and Manzoni, J. F. "The Balanced Scorecard and Tableau de Bord: A Global Perspective on Translating Strategy into Action. INSEAD Working Paper Series." 1997.

[cit: 25.9.2017]:

https://flora.insead.edu/fichiersti_wp/inseadwp1997/97-82.pdf

[29]Linczényi, A., Nováková, R. Quo Vadis quality management? In Quality as a concept of development, Proceeding: 19th International Symposium on Quality : Plitvička jezera, Hrvatska/Croatia, March 21st-23rd, 2018. 1. vyd. Zagreb: HDMK, 2018, pp. 112. ISBN 978-953-8067-11-2.

Date of sending the publication to the Editor: 20.06.2018 The date of the publication's acceptance by the Editorial Board: 24.07.2018 